\title{
Brainstem haematomas: review of the literature and presentation of five new cases
}

\author{
JOHN R MANGIARDI, * FRED J EPSTEIN $\dagger$ \\ From the New York Medical College, ${ }^{*}$ Division of Neurosurgery, Valhalla, and New York University Medical \\ Center, $\dagger$ Division of Neurosurgery, New York, USA
}

SUMMARY Fifty-one cases of brainstem haematoma that have undergone neurosurgical intervention since Finkelnburg's first exploration in 1905, are presented, together with five new cases. The location, incidence, aetiological and pathological factors, as well as clinical syndromes are reviewed. Diagnostic criteria are presented. The distinction between brainstem "haematoma" and "haemorrhage" is stressed. A retrospective comparison of 56 surgically treated cases and 31 conservatively managed cases is made, as is an analysis of the natural history of the disease process. Based on currently available data, the conclusion is drawn that patients with brainstem haematomas fare quite well after surgical therapy.

Nearly half a century after Finkelnburg first explored the brainstem for haematoma ${ }^{1}$ Teilmann $^{2}$ reviewed the world literature and provided summaries of 46 cases of documented vascular malformations of the pons. He thus established a new clinicopathological syndrome that (quoting McLean ${ }^{3}$ ) “... produces a kaleidoscopic wealth of signs which are ... a neurological delight for diagnosis, and neurosurgical despair for therapeusis."

With the advent of computed tomography and microsurgical techniques, the burdens of both diagnosis and "therapeusis" have become considerably lighter. Since the plea for surgical exploration of suspected lesions in the brainstem was made by Lassiter, et $a l,{ }^{4}$ in the hope of finding surgically approachable cystic tumours, a number of neurosurgeons have encountered and successfully drained unsuspected brainstem haematomas.

The purpose of this report is to document our experience with five patients harbouring brainstem haematomas, to present a comprehensive review of cases from the world literature that have undergone neurosurgical therapy, and to discuss views on the pathophysiology and management of these lesions.

Address for reprint requests: John $\mathrm{R}$ Mangiardi, MD, Division of Neurosurgery, New York Medical College, Munger Pavilion, Valhalla, New York, USA.

Received 5 June 1987 and in revised form 8 December 1987 Accepted 21 January 1988
Classification: Distinction of haematoma from hae- $\underset{2}{\vec{C}}$ morrhage

A careful distinction must be made between (1) focal subependymal brainstem haematoma, and (2) diffuse tegmentobasilar hypertensive haemorrhage (fig 1). The subependymal haematoma is most often the result of bleeding from a cryptic brainstem vascular malformation, usually telangiectasia. It is a focal, compressive lesion which displaces rather than destroys brain tissue. It occurs in a younger age group and causes neurological deficits which are often partially reversible.

Hypertensive brainstem haemorrhage usually causes a diffuse lesion occurring in an older age group and most often associated with profound, irreversible neurological deficits which are often fatal.

Arseni and Stanciu 5 described two similar groups of patients: "Group I" and "Group II". Papo, et al ${ }^{6}$ referred to "intra-axial" and "subependymal" haematomas. Goto, et $\mathrm{al}^{7}$ spoke of "tegmentobasilar" and "tegmental" haematomas. "Group II", "tegmental", and "subependymal" all describe the same lesion-the brainstem haematoma. It is usually limited by the ependyma of the fourth ventricular floor, although there may occasionally be leakage into the ventricular system, causing bloody CSF and nuchal rigidity. There may be extension laterally (mimicking a cerebellopontine angle tumour), or toward the brachium pontis. 


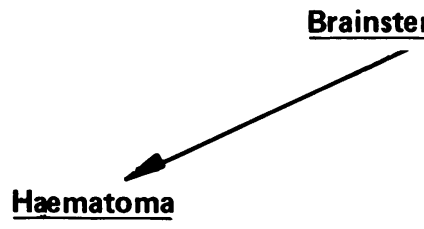

bleed

Subependymal

Focal lesion

Assoc. with vascular malformation

Younger age group

Intraventricular extension infrequent

Surgical lesion

Prognosis good

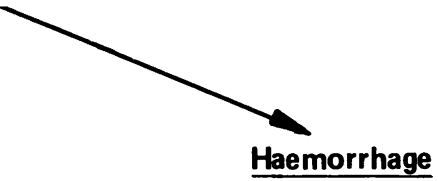

Deep tegmentobasilar

Diffuse lesion

Assoc. with hypertension

Older age group

Ventricular extension frequent

Nonsurgical lesion

Prognosis poor

Fig 1 Distinction between the focal subependymal brainstem haematoma and the diffuse tegmentobasilar hypertensive haemorrhage. The subependymal haematoma is most often the result of bleeding from a cryptic brainstem vascular malformation, usually a telangiectasia. It is a focal, compressive lesion which displaces rather than destroys brain tissue. It causes neurological deficits which are often partially reversible. The hypertensive brainstem haemorrhage results in profound, irreversible neurological deficits which are usually fatal.

\section{Case material}

\section{Location}

Among a series of 51 cases collected from the literature, one medullary and five midbrain haematomas are recorded; the remainder were pontine.

\section{Incidence}

Brainstem haematomas are rare. The incidence of both haematomas and haemorrhages in various necropsy series ${ }^{8-11}$ has been noted to be between $6 \%$ and $9 \%$ of all intracranial haematomas. Dinsdale, ${ }^{8}$ in a review of 19,000 necropsies, found 30 cases of haemorrhagic brainstem lesions, 27 of which had ruptured into the fourth ventricle; three of these were brainstem haematomas.

The range of ages in this series is from 17 months to 65 years, with a mean age of 24 years. Seventeen patients were under 16 years of age.

\section{Aetiological and pathological factors}

It appears that the fatal brainstem haemorrhages are hypertensive in origin as has been noted in various necropsy series. ${ }^{89}$ Alternatively, non-fatal subependymal brainstem haematomas evolve differently, arising from the vascular malformations described below. Hypertension does not appear to play a role (having been noted in only three of the 56 cases outlined in table I).

Virchow ${ }^{11}$ first reported a haemangioma of the pons as an incidental finding at necropsy in 1851. Cushing and Bailey ${ }^{12}$ elucidated the microscopic description of capillary telangiectasia, and noted that the floor of the fourth ventricle is a favoured site for them, most commonly in the upper pons. Russell ${ }^{13}$ coined the phrase "cryptic vascular malformation" using it to describe angiomatous malformations which measure less than $2-3 \mathrm{~cm}$ in maximum dimension. Of the 85 brainstem cryptic vascular malformations reviewed by McKormick and Nofzinger, ${ }^{14}$ more than 10 haematomas due to cryptic telangiectasia were noted. Gerlach ${ }^{15}$ spoke of "microangiomas", defining them as malformations under 2 $\mathrm{cm}$ in diameter. With recent technology, the size of a "cryptic" lesion has been reduced considerably.

Courville ${ }^{16}$ commented on the tendency of these lesions to separate rather than destroy pontine fibres, thus accounting for their quiescent clinical status prior to rupture.

Teilmann ${ }^{2}$ retrospectively reviewed 45 case of necropsydocumented pontine haemangiomas, nearly half of which were telangiectasias, one third were cavernous haemangiomas, and the remainder were venous or arteriovenous malformations.

On the other hand, Cole and Yates ${ }^{17}$ postulated that the most likely cause of the primary pontomedullary haemorrhages would be a microaneurysm arising from the vertebrobasilar arterial system. However, no such lesion has been noted in this review.

Margolis et al $^{\mathbf{1 8}}$ proposed that haematomas arising from cryptic malformation often result in the destruction of the anomalies when they bleed, thereby accounting for the high incidence of negative histological findings among such specimens. This has been true even when the wall of the haematoma has been biopsied. Of the 56 haematomas summarised in table I, only 13 cases had positive pathological reports given. Eleven cryptic malformations and one venous angioma were noted. In one case, ${ }^{19}$ a recurrent pontine haemangioblastoma, complete with mural nodule, was found at necropsy in the site of a previously removed haematoma.

Antecedent trauma, usually minor, was noted in four of the surgically treated brainstem haematomas. Currier $e a^{20}$ noted a similar incidence $(3 / 39)$ in patients with medullary infarction.

\section{Clinical syndromes}

Pathophysiologically brainstem cryptic malformations are congenital lesions that probably remain asymptomatic until they bleed. Periodic bleeding of small volume may explain the relapsing clinical course often noted. In some cases, 
Table 1 (a) Patient characteristics

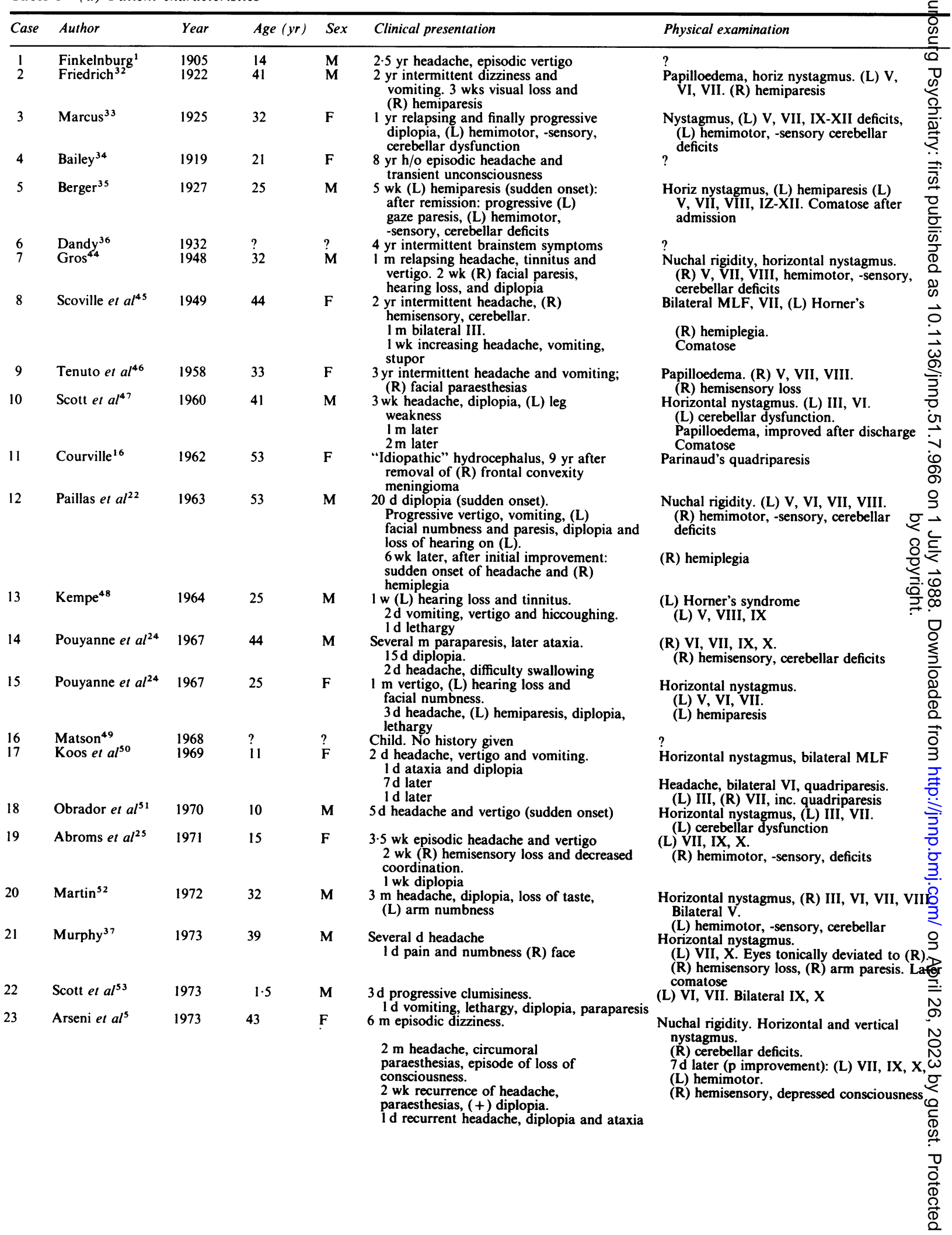


Table 1 (a) Continued

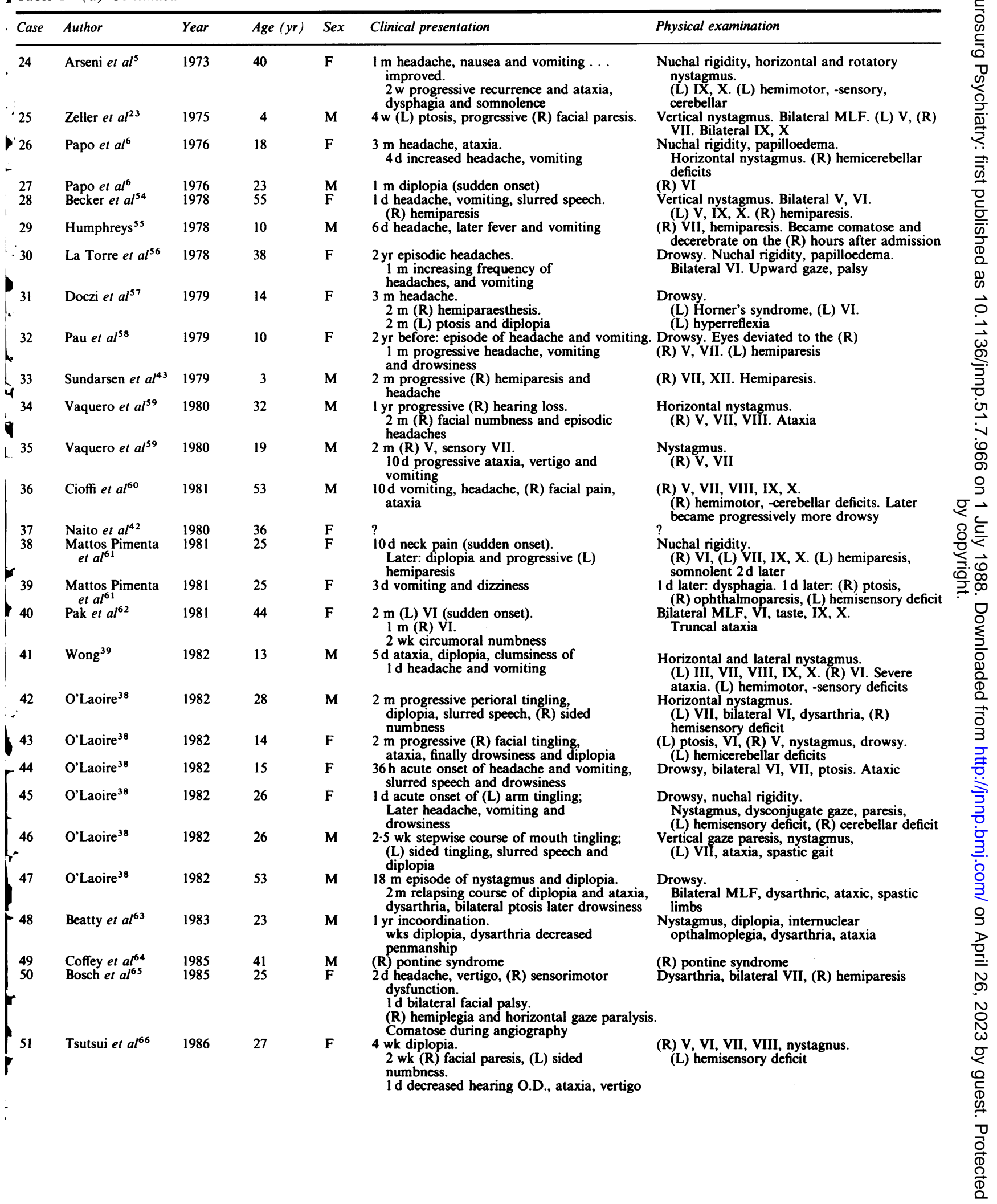


Table 1 (a) Continued

\begin{tabular}{|c|c|c|c|c|c|c|}
\hline Case & Author & Year & $\operatorname{Age}(y r)$ & Sex & Clinical presentation & Physical examination \\
\hline 52 & Case A & 1985 & 10 & $\mathbf{M}$ & $\begin{array}{l}5 \mathrm{~d} \text { headache, }(R) \text { facial paresis. } \\
\text { I d recurrent headache, diplopia, ataxia }\end{array}$ & $\begin{array}{l}\text { (R) VI, VII, nystagmus. } \\
\text { (R) hemicerebellar syndrome, ataxia }\end{array}$ \\
\hline 53 & Case B & 1983 & 14 & $\mathbf{M}$ & $\begin{array}{l}6 \text { yr petit mal seizures. } \\
5 \text { yr (L) VI N paresis. Treated with } R / T \text { and } \\
\text { chemo Rx. } \\
1 \text { yr (L) VI again, }(+)(L) \text { ptosis, progressive } \\
\text { (R) hemiparaesthesias, headache, vertigo, } \\
\text { personality change }\end{array}$ & $\begin{array}{l}\text { (L) VI, VII palsies, bilateral ML. } \\
\text { Truncal ataxia, (L) cerebellar deficits }\end{array}$ \\
\hline 54 & Case C & 1983 & 12 & $\mathbf{F}$ & $\begin{array}{l}2 \text { yr acute personality change, transient } \\
\text { episodic "fainting spells" } \\
2 \text { m recurrent personality change. } \\
6 \text { wk unsteady gait, slurred speech. } \\
\text { Later diplopia, vomiting, uncoordination }\end{array}$ & $\begin{array}{l}\text { Agitated, (R) III, (L) VI, VII, slurred speech, } \\
\text { truncal ataxia, (R) cerebellar }\end{array}$ \\
\hline 55 & Case D & 1984 & 42 & $\mathbf{F}$ & $\begin{array}{l}\text { Acute onset of dysarthria, numbness of }(R) \\
\text { cheek, dysphagia, mild }(R) \text { hemiparesis }\end{array}$ & $\begin{array}{l}\text { (L) facial palsy, }(R) \text { arm and leg dysmetria } \\
\text { with decreased tone, mild }(R) \text { hemiparesis }\end{array}$ \\
\hline 56 & Case E & 1973 & 65 & $\mathbf{M}$ & $\begin{array}{l}13 \text { yr relapsing diplopia. } \\
11 \text { yr severe headache, bilateral ptosis, (L) } \\
\text { VI, VIII. } \\
9 \text { yr progressive dysarthria, dysphagia, ataxia. } \\
1 \text { wk recurrent headache and disorientation }\end{array}$ & $\begin{array}{l}\text { Bilateral ptosis, papilloedema. } \\
\text { (L) VI, VII, VIII, bilateral IX, X. } \\
\text { Impaired memory and orientation }\end{array}$ \\
\hline
\end{tabular}

Table 1 (b) Operation and result

\begin{tabular}{|c|c|c|c|c|}
\hline Case & Operation & Time to operate & Follow-up & Results \\
\hline 1 & Post fossa trephine and cerebellar puncture & $?$ & - & Expired \\
\hline 2 & Post fossa trephine and cerebellar puncture & 12 hours & 1 day & Expired \\
\hline 3 & ? & 1 day & - & Expired \\
\hline 4 & Suboccipital craniectomy & & 8 years & Expired \\
\hline 5 & Parietal craniotomy & 3 weeks & 3 days & Expired \\
\hline 6 & Suboccipital craniectomy & $?$ & $?$ & Good (?) \\
\hline 7 & Suboccipital craniectomy & 8 days & 3 months & Improved, moderate deficit \\
\hline 8 & Transtentorial approach & 1 day & 7 years & Improved, mild deficit \\
\hline 9 & Torkildsen shunt & $?$ & 3 months & Improved, normal \\
\hline 10 & Suboccipital craniectomy & 4 months & 4 years & Improved, mild deficit (expired later) \\
\hline 11 & Ventriculo-atrial shunt & $?$ & 3 years & Expired \\
\hline 12 & Suboccipital craniectomy & 6 weeks & 4 weeks & Improved, moderate deficit \\
\hline 13 & Suboccipital craniectomy & 6 weeks & 6 months & Improved, normal \\
\hline 14 & Suboccipital craniectomy & 10 days & 3-4 months & Improved, severe deficit \\
\hline 15 & Suboccipital craniectomy & 4 days & 2 weeks & Improved, normal \\
\hline 16 & Suboccipital craniectomy & $?$ & $?$ & Improved (?) \\
\hline 17 & Suboccipital craniectomy & 10 days & 2 years & Improved, normal \\
\hline 18 & Suboccipital craniectomy & 1 day & 1 year & Improved, mild deficit \\
\hline 19 & Suboccipital craniectomy & 3 weeks & 3 years & Improved, moderate deficit \\
\hline 20 & Suboccipital craniectomy & 10 days & 1 month & Improved, normal \\
\hline 21 & Suboccipital craniectomy & 14 hours & 1 year & Improved, moderate deficit \\
\hline 22 & Suboccipital craniectomy & 6 days & 6 months & Improved, moderate deficit \\
\hline 23 & Suboccipital craniectomy & 15 days & 2 months & Improved, moderate deficit \\
\hline 24 & ? & 3 days & 1 month & Improved, mild deficit \\
\hline 25 & Ventriculo-peritoneal shunt & 15 days & 6 weeks & Expired \\
\hline 26 & Suboccipital craniectomy & 6 days & 1 year & Improved, mild deficit \\
\hline 27 & Suboccipital craniectomy & 7 weeks & 1 week & Post-op clot on CT scan \\
\hline 28 & Suboccipital craniectomy & 12 hours & 2 years & Improved, moderate deficit \\
\hline 29 & Suboccipital craniectomy & 1 day & 7 months & Improved, mild deficit \\
\hline 30 & Infratentorial supracerebellar approach & 1 day & 7 months & Improved, normal \\
\hline 31 & Suboccipital craniectomy & 1 week & I week & Improved, normal \\
\hline 32 & Suboccipital craniectomy & 1 week & I week & Improved, moderate deficit \\
\hline 33 & Suboccipital craniectomy & 1 week & 1 month & Improved, mild deficit \\
\hline 34 & Suboccipital craniectomy & 1 week & 3 years & Improved, normal \\
\hline 35 & Suboccipital craniectomy & 1 week & 2 years & Improved, normal \\
\hline 36 & Suboccipital craniectomy & l week & 1 year & Improved, moderate deficit \\
\hline 37 & Suboccipital craniectomy & 15 days & 4.25 years & Improved, mild deficit \\
\hline 38 & Suboccipital craniectomy & 4 days & 5 weeks & Improved, mild deficit \\
\hline 39 & Suboccipital craniectomy & 4 days & 1 year & Improved, normal \\
\hline 40 & Suboccipital craniectomy & 1 week & 6 months & Improved, mild deficit \\
\hline 41 & Suboccipital craniectomy & 1 week & 6 months & Improved, mild deficit \\
\hline 42 & Suboccipital craniectomy & $?$ & 9 months & Improved, normal \\
\hline 43 & Suboccipital craniectomy & $?$ & 3 months & Improved, normal \\
\hline 44 & Suboccipital craniectomy & $?$ & 2 years & Improved, normal \\
\hline 45 & $?$ & $?$ & 3 months & Improved, normal \\
\hline 46 & Suboccipital craniectomy & $?$ & 3 months & Improved, mild deficit \\
\hline 47 & Suboccipital craniectomy & $?$ & 3 weeks & Expired \\
\hline 48 & Stereotactic aspiration & 1 day & 1 month & Improved, mild deficit \\
\hline
\end{tabular}




\begin{tabular}{|c|c|c|c|c|}
\hline Case & Operation & Time to operate & Follow-up & Results \\
\hline 49 & Suboccipital craniectomy & $?$ & 9 months & Improved, mild deficit \\
\hline 50 & Stereotactic aspiration & $?$ & 6 months & Improved, moderate deficit \\
\hline 52 & Suboccipital craniectomy & 3 days & 1 year & Improved. moderate deficit \\
\hline 53 & Suboccipital craniectomy & 7 weeks & 4 years & \\
\hline 54 & Ventriculo-peritoneal Shunt & 1 year & 5 years & Expired \\
\hline 55 & Suboccipital craniectomy & 1 year & 1 year & Unchanged, moderate deficit \\
\hline
\end{tabular}
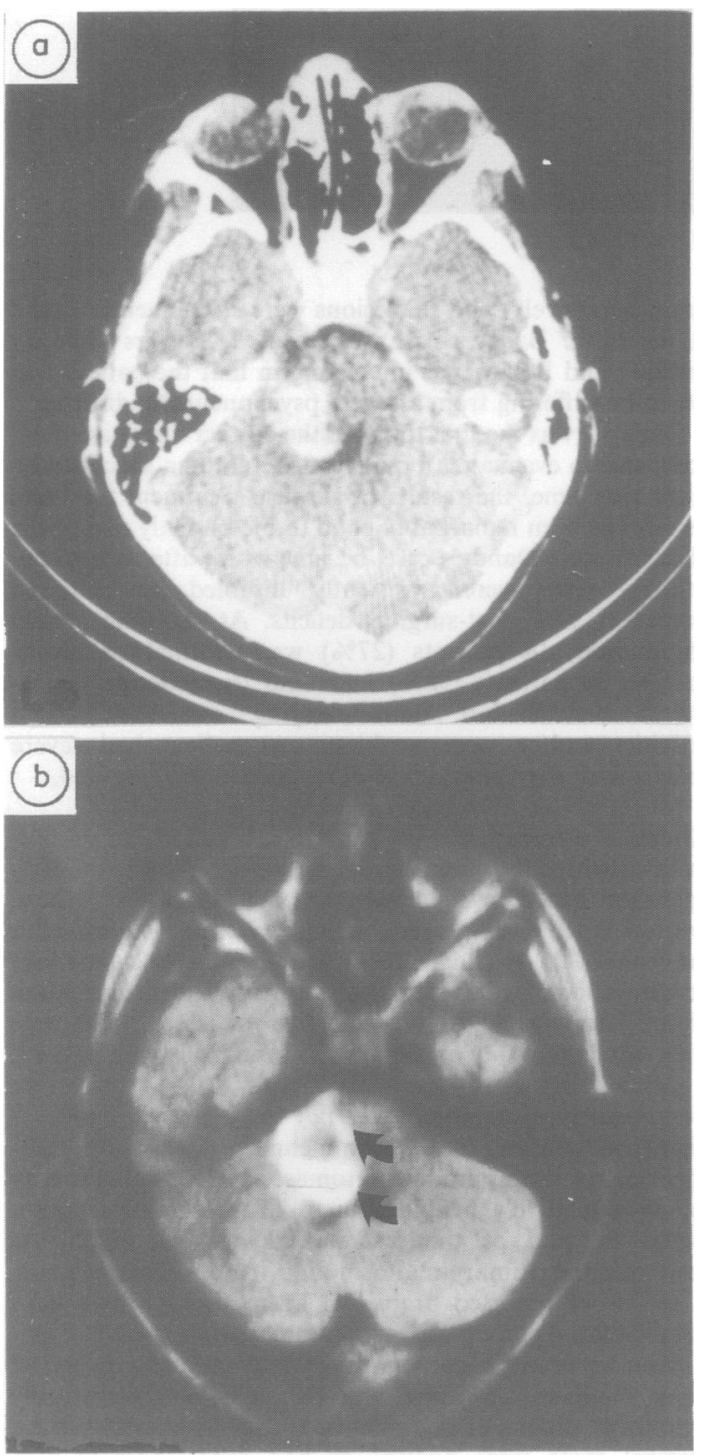

Fig 2 (a) Non-contrast CT scan discloses a blood density subependymal mass of the fourth ventricle on the right side. extending towards the brachium pontis (CASE A). (b) $M R I$ of the same subependymal haematoma. Arrow's point to two separate areas of haematomas (CASE $A$ ). small haematomas in strategic locations (Cases 21, 6) may cause major clinical symptoms. However, the severity of bleeding most often correlates with the degree of brainstem compromise.

In those cases where the bleed is of sufficient force to cause autodestruction of the primary lesion, the process is self limiting. This explains why the subgroup of brainstem haematomas may do so well clinically, even with conservative management. In cases where the vascular malformation persists, recurrent bleeding may occur even after surgical evacuation of the haematoma (Case 22). Recurrent bleeding usually leads to more severe symptomatology.

In Teilmann's review of pontine haemangiomas, ${ }^{2} 20 \%$ were asymptomatic during life and were incidental findings at necropsy. Thirty percent had no focal symptoms, but showed signs of diffuse cerebral dysfunction (dementia, personality changes, seizures, etc.) The remainder had focal symptoms suggestive of brainstem disease, with or without diffuse cerebral symptoms. In patients with brainstem findings, a characteristic pattern was encountered (usually in young persons and children) of acute or subacute episodes of pontine dysfunction, typically improving between episodes, but incompletely so. Often, a final common pathway of deterioration would be followed, either due to increased intracranial pressure (secondary to obstructive hydrocephalus), or recurrent haemorrhage. Zeller ${ }^{23}$ described a similar picture in children.

Pouyanne et $a l^{24}$ stressed the inexorably progressive course that some of these lesions take, mimicking brainstem tumours.

Arseni and Stanciu 5 described a two-stage evolution of the pontine haematomas, marked first by an ictal onset, and followed by a relatively rapid progression of symptoms. They also noticed the occasional "pseudo-onset" which could precede ictal symptomatology by months to years. This was interpreted as representing the effect of the primary process (cryptic malformation with associated vascular phenomena within the tight quarters of the brainstem) rather than the formation of an early haematoma.

Occasionally the course is stereotyped, there being an ictus, partial remission and subsequent recurrence. Rebleeding from the primary cryptic malformation might explain such a course, as suggested by Abroms. ${ }^{25}$ These cases have been misdiagnosed as multiple sclerosis on occasion. $^{26}$

Purely acute symptom courses occur more rarely and are usually related to sudden occlusion of the aqueduct with rapid neurological demise due to increased intracranial pressure and incipient tentorial herniation.

Some cases present only with the syndrome of obstructive hydrocephalus, undergoing shunting procedures alone with- 


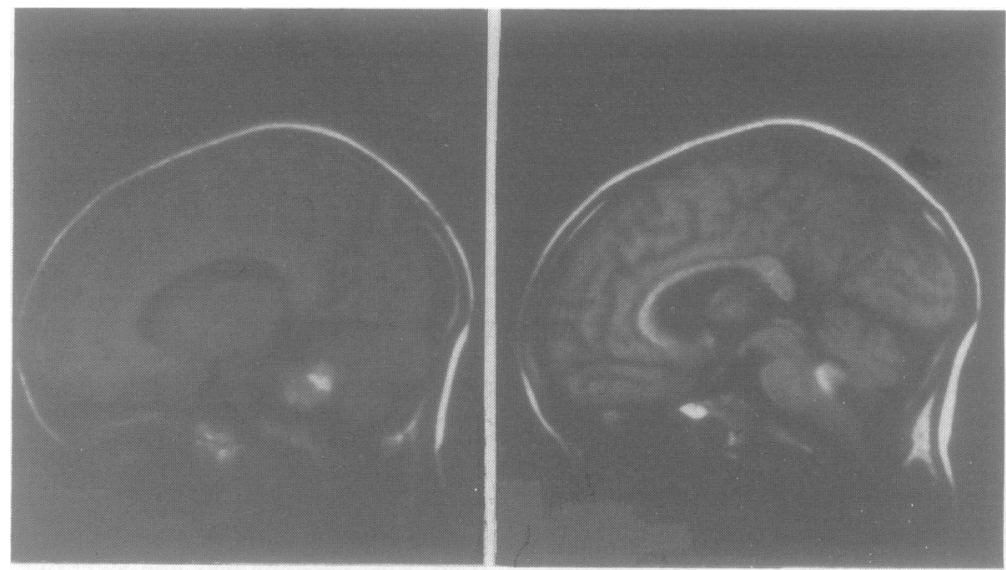

Fig 3 Saggital MRI on same lesion as fig 2 (CASE A).

out suspected brainstem disease (Case 21, 6). Misdiagnosis is relatively common: tumour, multiple sclerosis, or brainstem infarction are most frequently suspected.

\section{Diagnostic measures}

Computed tomography ${ }^{2728} 29$ may accurately help in the diagnosis of the brainstem haematoma. A high attenuation mass within the brainstem densiometrically consistent with blood, which does not enhance after contrast administration, is strongly suggestive of a brainstem haematoma, especially if subsequent studies show resolution of the density and persistent failure to enhance. A fluid : fluid interface may be seen within the haematoma (fig 5). On occasion, the computed tomogram may disclose some enhancement of the haematoma wall and it may be impossible to make the correct diagnosis preoperatively. ${ }^{2}$

Magnetic resonance imaging (MRI) accurately discloses location in sagittal view (fig 3). It may also show more than one haematoma, suggesting recurrent haemorrhage (fig $2 b$ ).

Lumbar puncture Bloody or xanthochromic fluid may be seen in cases where the haematoma has leaked through the ependymal floor of the fourth ventricle, suggesting a vascular rather than neoplastic aetiology. Frank bloody CSF may help distinguish hypertensive haemorrhage from subependymal haematoma. Of the 22 cases that underwent lumbar puncture in this series, 10 showed evidence of blood in the spinal fluid.

Cerebral posterior fossa angiography is not capable of providing adequate resolution to disclose cryptic malformations. ${ }^{303115}$ Of the 30 patients who were studied angiographically in this series, no preoperative study was reported to have disclosed a vascular anomaly. The angiogram may show evidence of a pontine mass and may outline local vascular anatomy, but it does not differentiate between the haematoma and primary intra-axial tumour.

\section{Results of surgical management (table 1)}

The first case of brainstem haematoma to be approached surgically was that of Finkelnburg ${ }^{1}$, who in 1903, explored a 14 year old boy with signs and symptoms of a posterior fossa obstructing mass lesion. In none of the first five cases $^{112333435}$ was the diagnosis of brainstem haematoma made operatively, and the lesions were subsequently found at necropsy. Bailey's case, ${ }^{34}$ presented 8 years later by Cushing and Bailey, ${ }^{12}$ is interesting in that the patient was felt to be suffering from a severe psychoneurotic disorder.

Dandy ${ }^{36}$ was the first to make the correct operative diagnosis and to evacuate a brainstem haematoma successfully. Since that time, the results of surgical treatment for these lesions has been remarkably good (table 2). Only two of the 51 cases, since Dandy's case, became worse after operation, although five were transiently disabled or acquired temporary new post-surgical deficits. At the time of last observation, 14 patients $(27 \%)$ were normal or nearly normal, 30 patients $(58 \%)$ had mild to moderate neurological deficits but were carrying out their usual activities and/or were working, one patient had severe deficits and was bedridden. Four patients $(8 \%)$ expired.

\section{Timing of surgery}

In cases where the clinical presentation is precipitous, early operation has been suggested. ${ }^{37}$ Some authors ${ }^{5224}$ have recommended timing surgery from 2 weeks to 1 month after the onset of the patient's most recent ictus, so that time may be allowed for local oedema to resolve and for delimitation of the haematoma by local reactive processes. ${ }^{5}$ The time from admission to operation in this series is listed in table 1 .

\section{Conservative versus surgical therapy (table 2)}

Numerous authors have recommended conservative management for brainstem haematomas, as some patients may follow a relatively benign course. The best case in point would be that of the discrete haematoma which has destroyed the primary malformation from whence it arose. A review of reported brainstem haematomas which have been managed conservatively is summarised in table 3. Comparison between the conservatively and surgically managed cases discloses an apparent, although not statistically significant, difference in outcome. Eighty-five percent of the surgical cases were normal or had mild-moderate neurological deficits, while only $30 \%$ of the conservatively managed group had similar results.

Conservatively managed cases rebleed with an unacceptably high frequency. When managed conservatively 

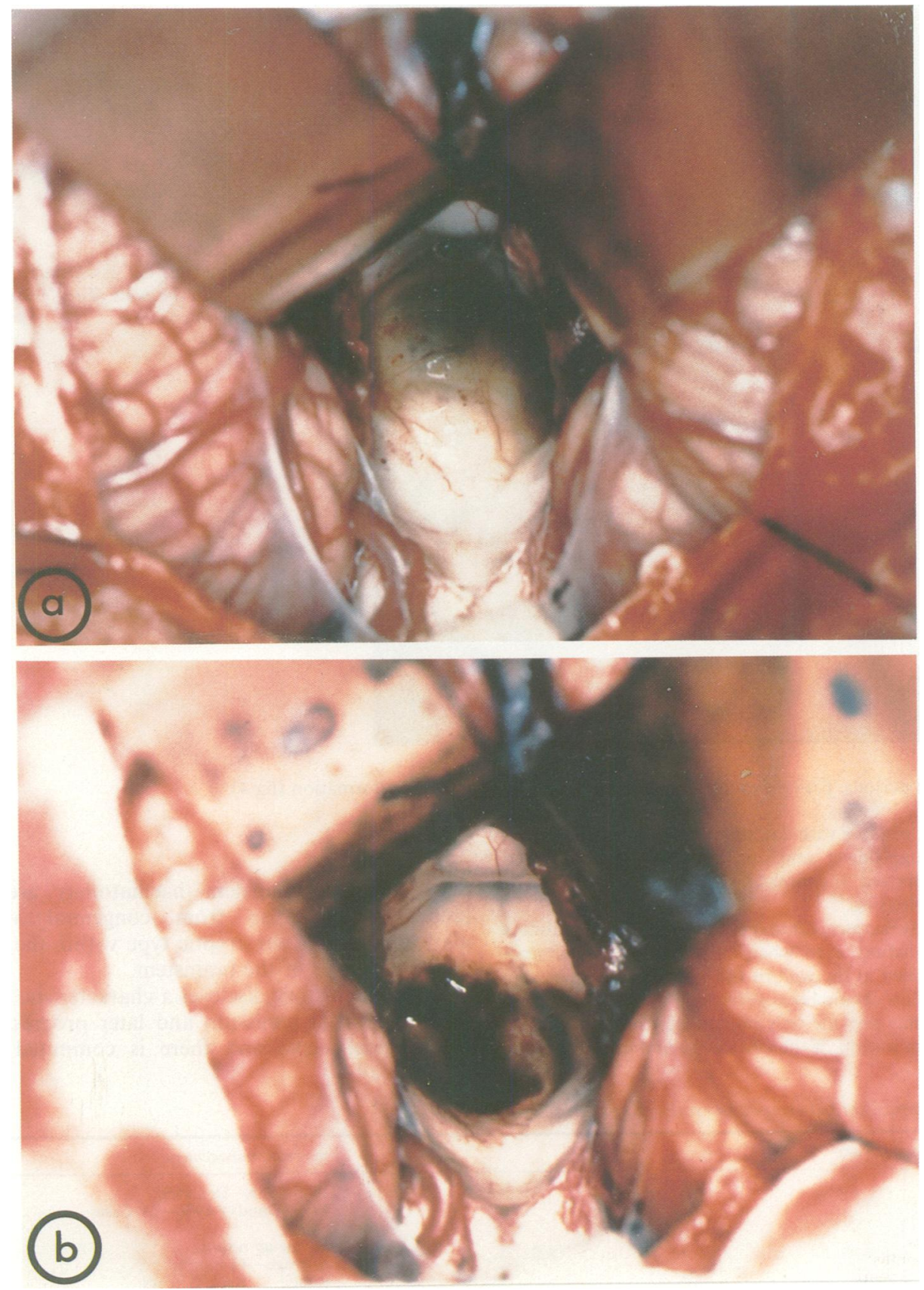

Fig 4 Operative photographs of brainstem haematoma (CASE B): (a) Prior to evacuation of haematoma, which elevated the floor of fourth ventricle on the left side displacing the median raphe. (b) After removal of haematoma, the cavity is seen after incision to the floor of the fourth ventricle. 


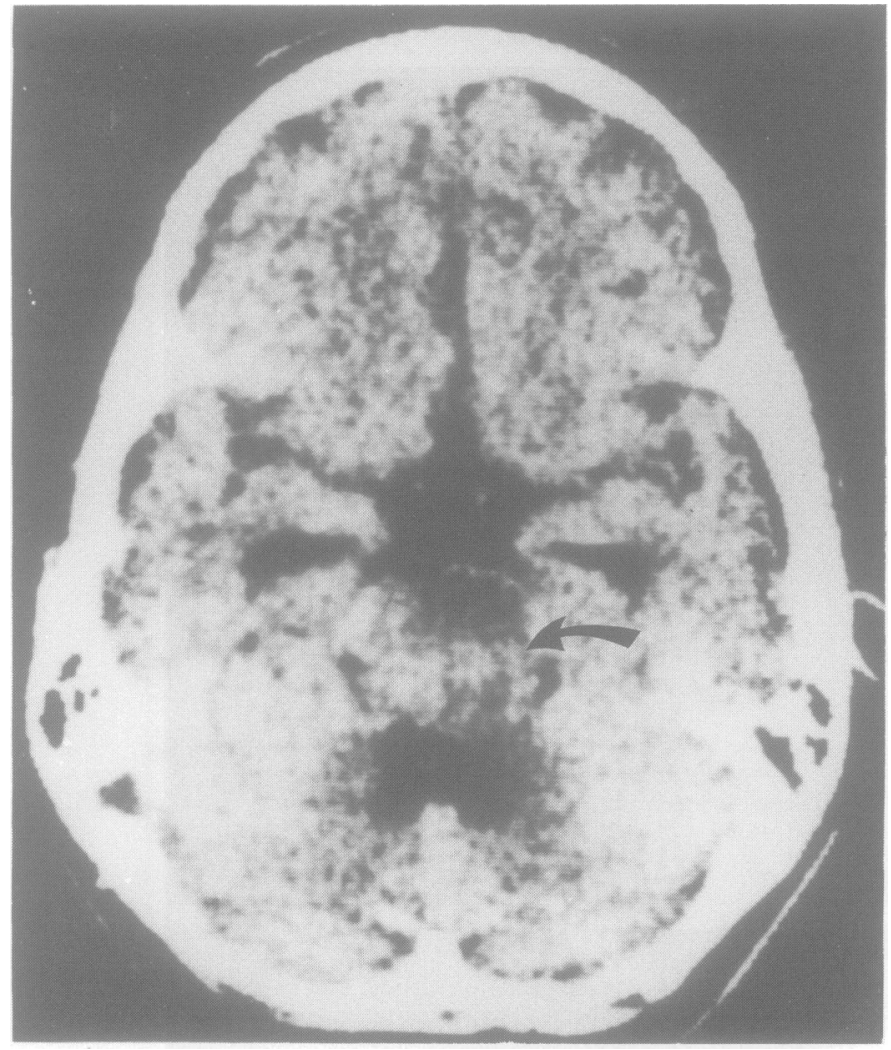

Fig 5 Non-contrast CT disclosing a fluid:fluid level in the pons. This lesion did not enhance with contrast.

for prolonged periods, patients eventually deteriorate (as did our Case A). ${ }^{41-43}$

At surgery, residual vascular malformation may be visualised under high-power magnification (we have observed three), and removed. If complete, such removal should obviate future rebleeding. ${ }^{38} 39$

Alternatively, surgical removal of the clot does not always preclude rebleeding, even when an obvious vascular malformation is seen in the wall of the clot with the operating microscope. This occurs because incision over the brainstem haematoma may provide only limited exposure, precluding adequate visualisation of the clot cavity and excision of the entire malformation (fig 4).

\section{Conclusions}

Subependymal brainstem haematomas are focal lesions which arise from congenital vascular malformations of the cryptic type within the closely packed confines of the brainstem.

When the history discloses a characteristic pattern of ictus, partial remission and later progression of neurological signs, and there is computed tomo-

Table 2 Comparison between conservatively and surgically managed cases

\begin{tabular}{|c|c|c|c|}
\hline \multicolumn{2}{|l|}{ Conservative management } & \multicolumn{2}{|l|}{ Surgical management } \\
\hline 33 Cases & & $\begin{array}{l}\text { 1905-1986-56 Cases } \\
1932 \text { (Dandy)-1986-51 Cases }\end{array}$ & \\
\hline $\begin{array}{l}\text { Follow-up results } \\
\text { Average-11 months } \\
\text { Range-2 days-5 years } \\
\begin{aligned} 5 & \text { Normal } \\
5 & \text { Mild-mod. deficit } \\
6 & \text { Severe deficit } \\
11 & \text { Expired } \\
6 & \text { Not evaluated } \\
\frac{1}{33} & \text { Total }\end{aligned}\end{array}$ & $\begin{array}{l}(15 \%) \\
(15 \%) \\
(18 \%) \\
(33 \%) \\
(18 \%)\end{array}$ & 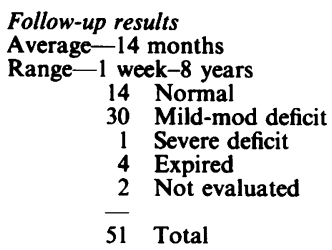 & $\begin{array}{r}(27 \%) \\
(58 \%) \\
(2 \%) \\
(8 \%) \\
(4 \%)\end{array}$ \\
\hline
\end{tabular}


Table 3 Conservative management of brainstem haematomas

\begin{tabular}{|c|c|c|c|c|}
\hline Authors & Year & Age (yr) & Time of follow-up & Result \\
\hline 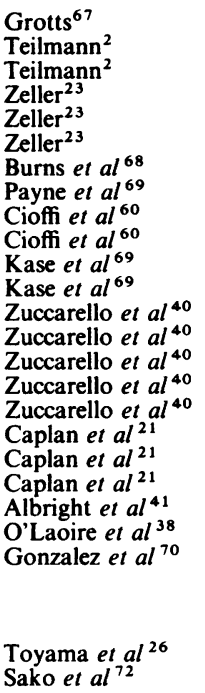 & $\begin{array}{l}1950 \\
1953 \\
1953 \\
1968 \\
1968 \\
1968 \\
1980 \\
1978 \\
1980 \\
1980 \\
1980 \\
1980 \\
1980 \\
1980 \\
1980 \\
1980 \\
1980 \\
1982 \\
1982 \\
1982 \\
1982 \\
1983 \\
1983\end{array}$ & $\begin{array}{c}2 \\
36 \\
47 \\
10 \\
18 \\
4 \\
58 \\
? \\
43 \\
55 \\
47 \\
42 \\
48 \\
10 \\
54 \\
57 \\
53 \\
81 \\
58 \\
63 \\
1 \cdot 5 \\
19\end{array}$ & $\begin{array}{l}2 \mathrm{D} \\
4 \mathrm{Y} \\
3 \mathrm{Y} \\
9 \mathrm{D} \\
3 \cdot 5 \mathrm{Y} \\
2 \mathrm{M} \\
37 \mathrm{D} \\
1 \mathrm{M} \\
2 \mathrm{Y} \\
7 \mathrm{M} \\
52 \mathrm{D} \\
48 \mathrm{D} \\
3 \mathrm{M} \\
2 \mathrm{M} \\
2 \mathrm{M} \\
2 \mathrm{~W} \\
2 \mathrm{M} \\
1 \mathrm{M} \\
3 \mathrm{~W} \\
18 \mathrm{M} \\
5 \mathrm{M} \\
5 \mathrm{Y}\end{array}$ & $\begin{array}{l}\text { Expired } \\
\text { Expired } \\
\text { Expired } \\
\text { Expired } \\
\text { Expired } \\
\text { Expired } \\
\text { Severe deficit } \\
\text { Mild deficit } \\
\text { Mild deficit } \\
\text { Severe deficit } \\
\text { Severe deficit } \\
\text { Severe deficit } \\
\text { "Improved" } \\
\text { Normal } \\
\text { Normal } \\
\text { Normal } \\
\text { Normal } \\
\text { Expired } \\
\text { Expired } \\
\text { Mod-severe deficit } \\
\text { Expired } \\
\text { Severe deficit } \\
9 \text { patients with discrete lesions: } \\
\quad 2 \text { expired } \\
\quad 1 \text { normal } \\
\quad \text { Others "improved" } \\
\text { Mild deficit } \\
\text { Mild deficit }\end{array}$ \\
\hline
\end{tabular}

graphic evidence of a discrete intra-axial lesion of blood density which does not enhance, the diagnosis of brainstem haematoma may be accurately made.

It appears from available evidence that these lesions probably fare better with surgical than with conservative management.

The surgical goals in the treatment of these lesions consist of (1) removal of the compressive lesion from within the brainstem, allowing for rapid return of neurological function, and (2) the obliteration of residual vascular malformation when observed, to prevent future rebleeding.

We thank Pamela A Miranda for her word processor assistance, Arlene Wise for her meticulous translations, and to Harry M Zimmerman, M.D., for his editorial assistance.

Addendum: Since submitting this paper, four more patients have been operated on for brainstem haematoma, with similar results to those of the first five patients.

\section{References}

1 Finkelnburg R. Zur differentialdiagnose zwischen kleinhirntumoren und chronischem hydrocephalus. (Zugleich ein beitrag zur kenntnis der angiome des zentralnervensystems.) In: Dtsch Z Nervenheikunde 1905;4:135-51.

2 Teilmann K. Hemangiomas of the pons. Arch Neurol Psychiatry 1953;69:208-23.

3 McLean AJ. In: Bumke O, Foerster O. Handbuch der Neurolgie. Berlin: Julius Springer, 1936;14:201.

4 Lassiter KRL, Alexander E Jr, Davis CH Jr, Kelly DL. Surgical treatment of brainstem gliomas. J Neurosurg 1971;34:719-25.

5 Arseni C, Stanciu M. Primary hematomas of the brainstem. Acta neurochir (Wein) 1973;28:323-30.

6 Papo I, Pasquini U, Salvolini U. Subependymal brainstem hematoma: A report of two cases. Neuroradiology 1976;11:279-82.

7 Goto N, Kaneko M, Hosaka Y, Koga H. Primary pontine hemorrhage: clinicopathological correlations. Stroke 1980;11:84-90.

8 Dinsdale HB. Spontaneous hemorrhage in the posterior fossa. A study of primary cerebellar and pontine hemorrhage with observations on their pathogenesis. Arch Neurol (Chicago) 1964;10:200-17.

9 Epstein AW. Primary massive pontine hemorrhage. A clinicopathological study. J Neuropathol Exp Neurol 1951;10:426-48.

10 Silverstein A. Primary pontine hemorrhage. In: Vinken PJ, Bruyn GW, eds. Handbook of Clinical Neurology. Amsterdam, American Elsevier, 1972;12:37-53.

11 Virchow R. Uber die erweiterung kleinerer gelfasse. Arch Pathol Anat 1851;3:427-62.

12 Cushing H, Bailey P. Tumors arising from the blood vessels of the brain: angiomatous malformations and hemangioblastomas. Springfield, Ill; Charles C Thomas, 1928:10-12.

13 Russell DS, Falconer MA, Beck DJK, Mcmenemey WH. The pathology of spontaneous intracranial hemorrhage. Proc $R$ Soc Med 1954;47:689-704.

14 McCormick WF, Nofzinger JD. Cryptic vascular malformation of the central nervous system. $J$ Neurosurg 1966;24:865-75.

15 Gerlach J. Intracerebral hemorrhage caused by microangioma. In: Krayenbühl H, Maspes PE, Sweet WH, eds. Progress in Neurological Surgery. Basel: S Karger, 1969;3:363-96.

16 Courville CB. Obstructive internal hydrocephalus incident to small vascular anomaly of midbrain. Report of case. Bull Los Angeles Neurol Soc 1961;26:41-5.

17 Cole FM, Yates PO. The occurrence and significance of intracerebral microaneurysms. J Pathol Bact 1967;93:393-411.

18 Margolis G, Odom GL, Woodhall B. Further experiences with small vascular malformations as a cause of massive intracerebral bleeding. J Neuropathol Exp Neurol 1961;20:161-7.

19 Myers J, Scott M, Silverstein A. Cystic hemangioblastoma of 
pons. J Neurosurg 1961;18:694-7.

20 Currier RD, Giles CL, De Jong RN. Some comments on Wallenberg's lateral medullary syndrome. Neurology 1961;11: 778-91.

21 Caplan LR, Goodwin JA. Lateral tegmental brainstem hemorrhages. Neurology 1982;32:252-60.

22 Pailles JE, Lesbros A, Bonnal J, Lavieille J, Jalfre M. Syndrome alterné par hématome de la protubérance. Opération. Revue Otoneuroophtal, 1963;35:100-1.

23 Zeller RS, Chutorian AM. Vascular malformations of the pons in children. Neurology 1975;25:776-80.

24 Pouyanne M, Got M, Julien J, Riemens V, Paoli M. Deux cas d'hématome intraprotubérantiels opérés. Étude critique. Soc Neurochir 1967;13:738-42.

25 Abroms IF, Yessayan L, Schillito J, Barlow CF. Spontaneous intracerebral haemorrhage in patients suspected of multiple sclerosis. J Neurol Neurosurg Psychiatry 1971;34:157-62.

26 Toyama $M$, Honda $H$, Ueki $K$. A case of spontaneous pontine haematoma in patients suspected of pontine glioma and multiple sclerosis. No Shinkei Geka (Neurological Surgery) 1978;6:1109-12.

27 Dhopesh VP, Greenberg JO, Cohen MM. Computed tomography in brainstem hemorrhage. J Comp Assist Tomogr 1980;4:603-7.

28 Muller HR, Wuthrich R, Wiggli U. This contribution of computerized axial tomography to the diagnosis of cerebellar and pontine hematomas. Stroke 1975;6:467-75.

29 Kowada M, Ito Z, Matsuoka S, Yamaguchi K. Primary pontine haemorrhage revealed by pneumoencephalo-roulette tomography, and a report on surgically treated cases. $J$ Neurol Neurosurg Psychiatry 1972;35:243-6.

30 Krayenbühl HA, Yasargil MG. Die Vascularen Erkrankungen in Gebut der Arterio Vertebralis und Arterio Basalis. Stuttgart: Georg Thieme, 1957:125-6.

31 Yasargil MG. Die vertebralisangiographie: Ihre bedeutung für die diagnostik der tumoren. Acta Neurochir Suppl 1962;9:82.

32 Friedrich $\mathrm{H}$, Stiehler $\mathrm{H}$. Ein hämangioendotheliom der medulla oblongata. Dsch Z Nervenheilk 1922;73:158-71.

33 Marcus $\mathrm{H}$. Tumorsymptome bei einigen erkrankungen im ponsund oblongata-gebiete. Folia Neuropathol Estoniara 1925;3:433-42.

34 Bailey $P$. Concerning the clinical classification of intracranial tumors. Arch Neurol Psychiat 1921;5:418-37.

35 Berger $H$, Guleke N. Uber hirntumoren und ihre operative behandlung. Dsch Z Neurochir 1927;204:104-67.

36 Dandy WE. The brain. In: D Lewis ed. Practice of Surgery. Hagerstown, MD: W Prior, 1932;12:673.

37 Murphy MG. Successful evacuation of acute pontine hematoma. Case report. J Neurosurg 1972;37:224-5.

38 O'Laoire SA, Crockard HA, Thomas DCT. Brainstem hematoma. A report of six surgically treated cases. J Neurosurg 1982;56:222-7.

39 Wong SK, Duffy PG. Surgical treatment of spontaneous pontine hematoma. J R Soc Med 1982;75:206-9.

40 Zuccarello M, Iavicoli R, Pardatscher K, Scanarini M, Fiore D, Andrioli GC. Primary brainstem haematomas. Diagnosis and treatment. Acta Neurochir 1980;54:45-52.

41 Albright LF, Byrd RP, Harrison ML. Angiographically cryptic AVM presenting as a pontine tumor. $J$ Neurosurg 1980;53:846-8

42 Naito M, Kitaoka T, Tomihara K, Uozumi T. A case of surgically cured atypical intrapontine hematoma. No Shinkei Geka (Neurological Surgery) 1980;8:199-203.

43 Sundaresan N, Galicich J, Krol G, Rosen G. Successful surgical treatment of pontine vascular malformation in a 3 year old. Case report. Child's Brain 1979;5(2):131-6.

44 Gros C, Giraud G, Latour H. Hématome spontané de la calotte protubérantielle, opéré et guéri. Presse Med 1949;56:890.

45 Scoville WB, Poppen JL. Intrapeduncular hemorrhage of the brain. Successful operative approach, with evacuation of clot and a seven and one-fourth year observation period. Arch
Neurol 1949;61:688-94.

46 Tenuto RA, Cruz OR. Hematoma intraprotuberancial. Arquivos Neuropsiquiatria (San Paulo) 1958;16:201-4.

47 Scott M, Silverstein A. Intrapontine cyst verified by surgical drainage into the fourth ventricle. Report of a case with an unusual neurological syndrome. J Neurosurg 1960;17:520-8.

48 Kempe LG. Surgical removal of an intramedullary haematoma simulating Wallenberg's syndrome. $J$ Neurol Neurosurg Psychiatry 1964;27:78-80

49 Matson DD. Surgery of posterior fossa tumor in childhood. In: J Shillito, Jr, (ed). Clin Neurosurg 1968;13:263-4.

50 Koos WT, Sunder-Plassman M, Salah S. Successful removal of a large intrapontine hematoma. Case report. $J$ Neurosurg 1969;31:690-4

51 Obrador S, Dierssen G, Odoriz BJ. Surgical evacuation of a pontine medullary hematoma. Case report. $J$ Neurosurg 1970;33:82-84

52 Martin P, Noterman J. L'hématome bulboprotubérantiel opérable. Acta Neurol Belg 1971;71:261-8.

53 Scott BB, Seeger JF, Schneider RC. Successful evacuation of a pontine hematoma secondary to rupture of a pathologically diagnosed "cryptic" vascular malformation. Case report. $J$ Neurosurg 1973;39:104-8.

54 Becker DH, Silverberg GD. Successful evacuation of an acute pontine hematoma. Surg Neurol 1978;10:263-6.

55 Humphreys RP. Computerized tomographic definition of mesencephalic hematoma with evacuation through pedunculotomy. Case report. J Neurosurg 1978;49:749-52.

56 La Torre E, Delitala A. Sorano V. Hematoma of the quadrigeminal plate. Case Report. J Neurosurg 1978;49:610-3.

57 Doczi T, Thomas GT. Successful removal of an intrapontine haematoma. J Neurol Neurosurg Psychiatry 1979;42:1058-61.

$58 \mathrm{Pau}$ A, Viale ES, Turtas S. Surgical removal of a pontine haematoma associated with a cryptic angioma. Case report. Acta Neurochir (Wien) 1979:50:299-303.

59 Vaquero J, Areitio E, Leunda G, Bravo G. Haematomas of the pons. Surg Neurol 1980;14:115-8.

60 Cioffi JA, Tomasello F, D'Avanzo R. Pontine hematomas. Surg Neurol 1980;16:13-6.

61 Mattos Pimenta LH, Mattos Pimenta A, Zuckerman E. Pontine haematoma. Successful removal of two cases with review of 22 cases previously described in accessible literature. Neurosurg $\operatorname{Rev~1981;4:139-42.}$

62 Pak H, Patel SC, Malki GM, Ausman JI. Successful evacuation of a pontine hematoma secondary to rupture of a venous angioma. Surg Neurol 1981;15:164-7.

63 Beatty RM, Zervas NT. Stereotactic aspiration of a brainstem hematoma. Neurosurgery 1983;13:204-7.

64 Coffey RJ, Lunsford LD. Stereotactic surgery for mass lesions of the midbrain and pons. Neurosurgery 1985;17:12-17.

65 Bosch DA, Beute GN. Successful stereotaxic evacuation of an acute pontomedullary hematoma. Case report. $J$ Neurosurg 1985;62:153-7.

66 Tsutsui T, Ohno M, Symon L, Wang A. Combined measurement of brainstem auditory and somatosensory evoked potentials in a surgically treated brainstem hematoma. Surg Neurol 1986;25:575-81.

67 Grotts BF. Spontaneous hemorrhage from a hemangioma of the pons. J Pediatr 1950;37:98-101

68 Burn J, Lisak R, Schut L, Silberberg D. Recovery following brainstem hemorrhage. c.nn Neurol 1980;7:183-4.

69 Kase CS, Maulsby GO, Mohr JP. Partial pontine hematomas. Neurol 1980;30:652-5.

70 Payne HA, Maravilla KR, Levinstone A, Heuter J, Tindall RS. Recovery from primary pontine hemorrhage. Ann Neurol 1978;4:557-8.

71 Gonzalez AC, Gallego JH, Sanchez AP. Brainstem hematomas. J Neurosurg 1983;58:456-7.

72 Sako K. Moriwaka F, Kishihara T, Nakagawa Y, Tashiro K. Abe $H$. Primary pontine hemorrhage in children-report of a case. No Shinkei Geka (Neurological Surgery) 1979;7:383-7. 